\title{
漢方専門外来受診患者における 漢方薬服用に関する塞態調查
}

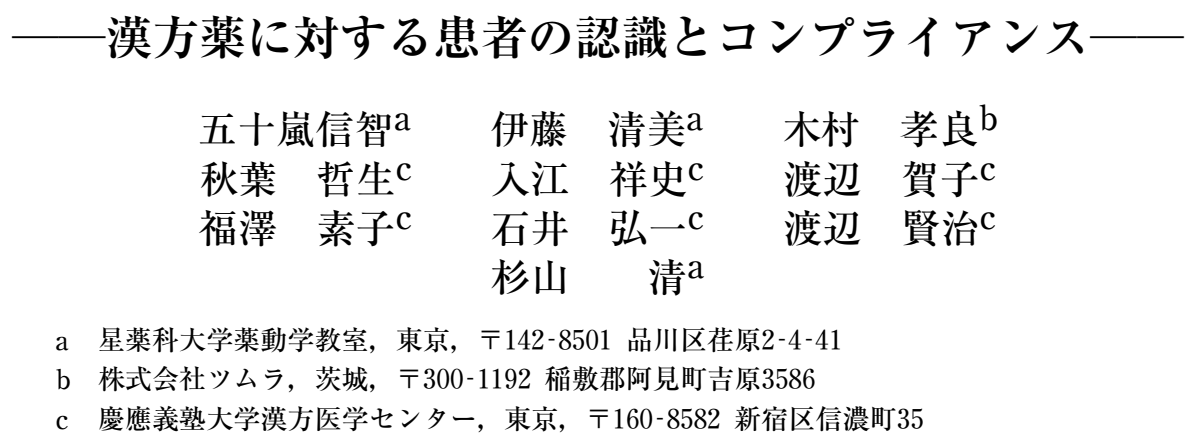

\section{Survey of the Use of Kampo Medicine at the Kampo Clinic -Patients' Perceptions and Compliance Regarding Kampo Medicines-}

\author{
Nobutomo IKARASHI $^{\mathrm{a}}$ Kiyomi ITO $^{\mathrm{a}}$ Takayoshi KIMURA $^{\mathrm{b}}$ \\ Tetsuo AKIBA ${ }^{\mathrm{c}} \quad{\text { Yoshifumi } \text { IRIE }^{\mathrm{c}} \text { Kako WATANABE }}^{\mathrm{c}}$ \\ Motoko FUKUZAWA $^{\mathrm{c}}$ Hirokazu ISHII ${ }^{\mathrm{c}}$ Kenji WATANABE ${ }^{\mathrm{c}}$ \\ Kiyoshi SUGIYAMA ${ }^{\mathrm{a}}$
}

a Department of Clinical Pharmacokinetics, Hoshi University, 2-4-41 Ebara, Shinagawa-ku, Tokyo 142-8501, Japan

b Tsumura \& Co., 3586 Yoshiwara, Ami-machi, Inashiki-gun, Ibaraki 300-1192, Japan

c Center for Kampo Medicine, Keio University School of Medicine, 35 Shinanomachi, Shinjuku-ku, Tokyo 160-8582, Japan

\begin{abstract}
Kampo medicines have been used for treatment by an increasing number of doctors in recent years, and are becoming more frequently prescribed in combination with Western drugs. In the present study, we conducted a questionnaire of outpatients at the Kampo Clinic of Keio University Hospital in order to determine their perceptions and compliance regarding Kampo medicines.

Ninety eight percent of patients used Kampo medicines in granular form, and approximately $30 \%$ of these patients reported difficulty in taking medicine due to reasons such as "bad taste". Sixty percent of patients used Kampo medicines three times daily. Patients most often forgot to take afternoon doses, and so desired doses once daily. Furthermore, the same number of patients preferred Kampo medicines in tablet form as those who preferred Kampo medicines in granular form.

The present findings clarified patients' perceptions toward Kampo medicines. Doctors and pharmacists must provide suitable treatment for patients by recognizing their perceptions of Kampo medicines.

Key words : Kampo medicine, compliance, survey, formulation

要旨

近年, 臨床において漢方薬を治療に用いる医師が増加し, 西洋薬とともに漢方薬が処方される機会が多くなって きた。本研究では，慶應義塾大学病院漢方クリニックに来院した外来患者を対象とし，漢方薬に対する患者の認識 およびコンプライアンスなどについてアンケート調査を行った。

98\%の患者が顆粒剤の漢方薬を服用しており，そのうち約 3 割は「味がまずい」などの理由で飲みにくいと回答 した。60\%の患者は漢方薬を1日3 回服用しているが，昼に飲み忘れる場合が多く，1日の服用回数として2回を 希望している患者が多かった。また，漢方薬の風形として顆粒剤と並んで錠剤を希望している患者が多かった。

本研究の結果より, 漢方専門外来受診患者の漢方薬に対する認識が明らかとなった。今後, 医師および薬剤師は,
\end{abstract}


漢方薬に対する患者のこのような認識を把握し，患者に適した治療を行っていく必要があると考えられる。 キーワード：漢方薬，コンプライアンス，アンケート調査，剤形

\section{緒言}

近年，臨床において漢方薬を治療に用いる医師が 増加し，西洋薬とともに漢方薬が処方される機会が 多くなってきた。2003年に一般の医師を対象に行わ れた漢方薬使用状況に関するアンケート調査では, 9 割の医師が漢方薬を使用したことがあると回答し ている11。このように漢方薬が臨床で盛んに用いら れるようになった理由としては，現在使用されてい
る西洋薬だけでは限界があること, 以前は漢方薬の 科学的デー夕が少なかったが, 近年, 漢方薬に関し ても明確なエビデンスを有する科学的データが報告 されるようになったこと, さらに患者が漢方薬の服 用を強く要望するようになったことなどが考えられ ている11。このように，漢方薬は現代医療に幅広く 用いられており, 今後さらに漢方薬の処方頻度が増 加すると考えられる。

表 1 アンケート用紙（抜粋）

【1】あなたについておうかがいします。

$1-1$ 年齢はおいくつですか?
1. 7 才未満
2. 7 才〜 14 才
3. 15 才 24 才
4. 25 才〜 34 才
5. 35 才〜 44 才
6. 45 才〜 54 才
7. 55 才〜 64 才
8. 65 才〜 74 才
9. 75 才〜 84 才
10. 85 才以上

1-2 あなたの性別はつぎのどちらですか?
1. 男
2. 女

1-3 今回、あなたが病院にかかられる原因となった疾患名または症状名は何 でしょうか?

【2】あなたの漢方薬の使用状況等についておうかがいたします。 2-1 漢方薬を服用してどのくらいになりますか?
1. 2 週間未満
2. 2 週間 $~ 1$ 力月未満
3. 1 力月 $~ 3$ 力月末満
4. 3 力月 6 力月未満
5. 6 力月 1 年未満
6. 1 年 $\sim 3$ 年末満
7. 3 年 $\sim 5$ 年未満
8. 5 年以上 $((\quad)$ 年)

$2-2$ 漢方薬を飲みはじめて、症状や体調はよくなりましたか?
1. 体調がよくなった
2. 変わらない
3. 体調が悪くなった
4. 病気が改善した
5. 病気が悪くなった
6. わからない

2-3 漢方薬を飲んでから、何か副作用がありましたか?
1.あった
2. ない
3.わからない

2-4 2-3であったと答えた方にお聞きします。その副作用はどのようなもの でしたか?（複数答えても構いません）
1. 腹痛
2. 下痢
3. 胃部不快感
4. 悪心・嘔吐
5. 湿疹
6. アレルギー症状
7. 発熱
8. 頭痛
9. その他

【3】あなたの漢方薬および漢方診療に関するお考えについておうかがいいた します。

3-1 漢方薬を飲むことに関してどのようにお考えですか?
1.ぜひ飲み続けたい
2. 飲むことに抵抗は無い
3. 出来れば飲みたくない
4. 今寸ぐにでも止めたい
5. その他（ 
3-2 漢方薬は長く飲まないと効かないと思いますか?

1. 思う $\Rightarrow$ あなたは漢方薬を飲んで、どの程度の期間、効かなか ったら漢方薬の使用を止めますか?
【1. 2 週間未満
2. 2 週間
4. 3 力月
5. 6 力月
6. 1 年
7. 3 年以上】

3. 1 力月

2. 思わない

3-3 あなたが、当漢方クリニックにかかられている理由はなんですか? （複数答えても構いません）

1. 今までの西洋医学の治療では治らなかったため

2. 漢方薬は副作用が少ないため

3. 漢方薬は効果が穏やかなため

4. 人に勧められたため

5. その他（ )

【4】あなたが最近飲まれている漢方エキス製剤についておうかがいします。 4-1 現在飲んでいる漢方エキス製剤は、1 日何回服用していますか?
1. 1 回
2. 2 回
3. 3 回
4. その他 (

4-2 漢方エキス製剤を飲んだときどのようにお感じになりましたか?（複数 答えても構いません）
1. 非常に飲みやすい
2. 飲みやすい
3. 普通
4. 飲みにくい
5. 非常に飲みにくい

4-3 4-2 で「非常に飲みにくい」あるいは「飲みにくい」と答えた方にお聞 きします。飲みにくいとお答えの理由を下記より選択してください。
1. 粉っぽくてむせてしまう
2. 入れ歯にはさまる

3. 1 回の飲む量が多い

4. 味がまずい（苦い・えぐい・すっぱいなど）

5. その他（

4-4＼cjkstart漢方エキス製剤を飲み忘れたことはありますか?

1. ない

2. ある $\Rightarrow$ 【1. 1 週間に 1 回程度 3. 1 週間に 3 回程度

2. 1 週間に 2 回程度

4. 1 週間に 4 回以上】

4-5 4-4 であると答えた方にお聞きします。飲み忘れの多い時期は何です か?（複数答えても構いません）
1. 朝
2 昼
3. 夕

【5】漢方エキス製剤に対するあなたの考え方についておうかがいします。

5-1 漢方エキス製剤の剂形としては、どのようなものが飲みやすいと思いま すか?（複数答えても構いません）
1. 顆粒剤 (粉)
2. 錠剂
3. カプセル剂
4. その他
的

$5-2$ 漢方薬を飲む回数として、どの程度が良いと考えますか?
1. 1 日 1 回
2. 1 日 2 回
3. 1 日 3 回
4. その他（

東洋医学は治療方針などが西洋医学と基本的に異 なっている。たとえば，西洋薬の用法は食後が多い のに対し, 漢方薬の用法については, 東洋医学の古 典および現在市販されている製剤の添付文書におい て，食前あるいは食間に服用することとされている。 また，西洋薬の凰形は錠剤やカプセル剂が主流であ
るのに対し, 漢方薬は多くの場合, 複数の生薬の煎 液を顆粒状あるいは細粒状にしたエキス製剤である。 このように，漢方薬の用法や剂形は西洋薬とは違う ため, 漢方薬の服用状況やコンプライアンスなどは 西洋薬とは異なる可能性が考えられる。

我々は前報 2 において, 慶應義塾大学病院の漢方 
表 2 漢方薬の服用期間について

\begin{tabular}{|c|c|c|c|}
\hline $\begin{array}{l}\text { 長く飲まないと効かないと思うか } \\
\text { (効くまでの予想服用期間) }\end{array}$ & $\begin{array}{l}\text { 人数 } \\
\text { (人) }\end{array}$ & 実際の服用期間 & $\begin{array}{l}\text { 人数 } \\
\text { (人) }\end{array}$ \\
\hline そう思う & 257 & 2 週間未満 & 10 \\
\hline 2 週間未満 & 2 & 2 週間 1 力月未満 & 20 \\
\hline 2 週間 & 14 & 1 力月 3 力月未満 & 57 \\
\hline 1 力月 & 38 & 3 力月 6 力月未満 & 55 \\
\hline 3 力月 & 50 & 6 力月 1 年未満 & 71 \\
\hline 6 力月 & 43 & 1 年 3 年未満 & 92 \\
\hline 1 年 & 67 & 3 年 5 年未満 & 49 \\
\hline 3 年以上 & 43 & 5 年以上 & 75 \\
\hline そう思わない & 115 & & \\
\hline 合計 & 372 & & 429 \\
\hline
\end{tabular}

専門外来（以下，漢方クリニック）に来院した外来 患者を対象にアンケート調査を実施し，漢方薬と西 洋薬の併用実態について解析を行った。その結果, 約半数の患者が漢方薬と西洋薬を併用していること, さらに併用が漢方薬のコンプライアンス低下の原因 となりうることなどを明らかにした。

本研究では，漢方薬の使用実態を把握するととも に，西洋医学とは異なる治療を行なう東洋医学に対 して，患者がどのような認識を持っているかを明ら かにする目的で, 前アンケート調査解析 ${ }^{2)}$ とは異な る視点からアンケート結果を解析した。

\section{方法}

アンケート調査は前報 ${ }^{2}$ と同様の方法で行い, 前 報で取り扱わなかった項目について解析を行った。 すなわち, 慶應義塾大学病院漢方クリニックにおい て，2004年 6 月～ 8 月の 2 力月間に来院した外来患 者を対象に, 患者背景, 漢方薬㧍よび東洋医学に対 する認識，漢方薬のコンプライアンスなどについて 調査を行い, 解析した（表 1 )。このアンケートに は医師，薬剤師は関与せず，患者に対し，看護師が 事前に調査趣旨およびデータの取り扱いに関する説 明を行った後，患者自身が自由に回答するという形 式で行った。また，調査は無記名とし，各設問にっ いて無回答の場合は解析対象から除外した。なお， 解析は新患，再来患者の区別なく行った。

\section{結果}

アンケートは，440人から回答が得られた。

漢方クリニックを受診している患者の内訳は男性 が121人 (28\%), 女性が314人（72\%）であった（回
答者 435 人)。また，35歳から64歳までの患者が 224 人 $(51 \%)$ で約半数を占め, 65 歳以上の患者は 113 人 $(26 \%) ， 34$ 歳以下の患者は 101 人 $(23 \%)$ であっ た (回答者 438 人 $)^{2)}$ 。

1 . 漢方薬の服用期間と患者の認識

漢方薬の服用期間について，「漢方薬は長く飲ま ないと効かないと思う」と回答した患者は 257 人 （69\%）であった（回答者372人)。これらの患者に 対して, どのくらい服用して効かなかったら漢方薬 の使用を中止するか，という質問では「1年」と回 答した患者が 67 人 $(26 \%)$ で最も多く，次いで「3 力月」が50人 $(20 \%) ， 「 6$ 力月」拉よび「 3 年以上」 が43人（17\%）であり，1 年以下の期間を挙げた患 者が214人（83\%）でほとんどであった（表 $2 ） 。$

これに対して，回答者429人の現在服用中の漢方 薬服用期間は，「 1 年 3 年未満」が92人 $(21 \%)$ で最も多く，次いで「5 年以上」が75人 $(18 \%), 「 6$ カ月～1年未満」が71人（17\%）であった（表 2）。 1 年以上漢方薬を服用している患者は216人 (50\%) で約半数を占め，その服用期間は平均 49.3 力月で あった。

1 年以上漢方薬を服用している回答者 194 人につ いて，漢方薬の服用に対する認識を調査した結果， 「飲むことに抵抗はない」と回答した患者が89人 (46\%)，「ぜひ飲み続けたい」と回答した患者が87 人 $(45 \%)$ おり，「出来れば飲みたくない」と回答 した患者 15 人（8％) を大幅に上回った。

2. 漢方クリニックの受診理由

回答者 406 人の漢方クリニック受診理由について 
表 3 漢方クリニック受診理由と症状の変化

(a) 受診理由

\begin{tabular}{lr}
\hline 今までの西洋医学の治療では治らないため山 & 185 人 \\
漢方薬は副作用が少ないため & 152 \\
漢方薬は効果が穏やかなため & 99 \\
人に勧められたため & 58 \\
その他 & 26 \\
\hline 合計 & 406 \\
\hline
\end{tabular}

（b）上記症例 のの原疾患と漢方治療後の症状の変化

（複数回答可、回答者 185 人）

\begin{tabular}{lclc}
\hline 原疾患領域 & 人数 $($ 人) & 症状の変化 & 人数 $(人)$ \\
\hline 皮膚科疾患 & 40 & 体調が良くなった & 96 \\
産婦人科系疾患 & 31 & 病気が改善した & 39 \\
消化器疾患 & 27 & 変わらない & 26 \\
精神疾患 & 22 & 体調が悪くなった & 8 \\
神経・筋疾患 & 22 & わからない & 26 \\
耳鼻咽喉科疾患 & 17 & & \\
整形外科疾患 & 12 & & \\
代謝・内分泌疾患 & 8 & & \\
癌・悪性腫瘍 & 8 & & \\
呼吸器疾患 & 8 & & \\
\hline
\end{tabular}

表 4 顆粒剂の漢方薬が飲みにくい理由

（複数回答可，回答者 112 人）

\begin{tabular}{lc}
\hline 飲みにくい理由 & 人数（人) \\
\hline 味がまずい（苦い・えぐい・すっぱいなど） & 64 \\
粉っぽくてむせてしまう & 19 \\
1 回の飲む量が多い & 11 \\
入れ歯にはさまる & 9 \\
その他 & 18 \\
\hline
\end{tabular}

は，「今までの西洋医学の治療では治らなかったた め」と回答した患者が最も多く 185 人 (46\%) であ り, 患者全体の約半数を占め, 次いで「漢方薬は副 作用が少ないため」，「漢方薬は効果が穏やかなた め」などの回答があった（表 3 - $\mathbf{a})$ 。

「今までの西洋医学の治療では治らなかったた め」と回答した患者の原疾患について解析した結 果，皮膚科疾患が最も多く 40 人（22\%）であった

(表 3-b)。また,「今までの西洋医学の治療では 治らなかったため」と回答した患者の漢方薬服用後 の症状の変化については，「体調が良くなった」と 回答した患者が96人 $(52 \%)$ ，「病気が改善した」と 回答した患者が39人 $(21 \%)$ であった（表 3-b）。

3. 漢方薬の服用状況とコンプライアンス

服用している漢方薬の剂形としては顆粒剤が98\%
と多く，そのほかに錠剤，湯剂などがあった ${ }^{2)}$ 。 回答者 403 人のうち 113 人 $(28 \%)$ が顆粒剤の漢方 薬の服用について，「非常に飲みやすい」あるいは 「飲みやすい」と回答した。その一方，112人 (28\%) の患者が顆粒剤の漢方薬を「飲みにくい」あるいは 「非常に飲みにくい」と回答した。顆粒剂の漢方薬 が「飲みにくい」あるいは「非常に飲みにくい」理 由については，「味がまずい」と回答した患者が最 も多く64人 $(57 \%)$ おり，半数以上を占めた。また その他に「粉っぽくてむせてしまう」，「1回の飲む 量が多い」，「入れ歯にはさまる」などの理由で顆粒 剂の漢方薬を飲みにくいと回答していた（表 4 ）。

漢方薬の飲み忘れについては，回答者379人のう ち103人 $(27 \%)$ が漢方薬を「飲み忘れたことがな

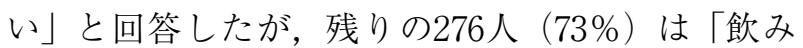
忘れたことがある」と回答した（図 1 )。漢方薬を 


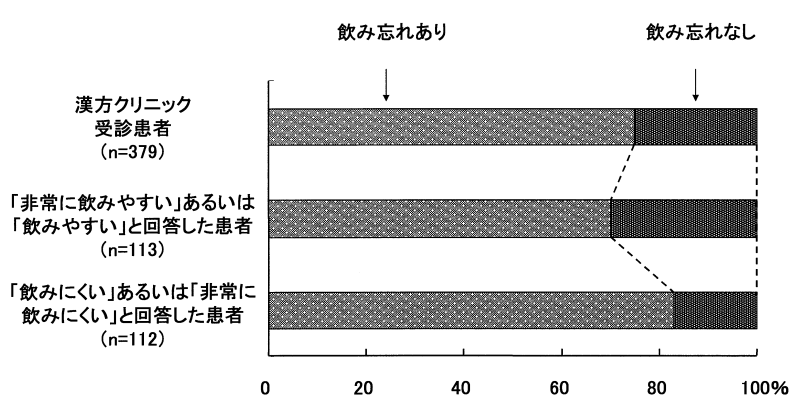

図 1 漢方薬の飲み忘れと顆粒剂の飲みやすさとの関係

「飲み忘れたことがある」と回答した患者の飲み忘 れの頻度としては，「1週間に 1 回程度」が111人 $(40 \%), 「 2$ 回程度」が 82 人 $(30 \%), 「 3$ 回程度」 が51人 (18\%)，「4 回以上」が32人 (12\%) であっ た。また，飲み忘れの多い時期としては，「昼」が 172 人 $(62 \%)$ で最も多く, 次いで「朝」が104人 (38\%),

「夕」が 85 人 (31\%) であった。

顆粒剤の漢方薬を「非常に飲みやすい」あるいは 「飲みやすい」と回答した患者 113 人のうち，「飲み 忘れたことがある」と回答した患者は80人 (68\%) であった。一方，「飲みにくい」あるいは「非常に 飲みにくい」と回答した患者 112 人では93人 (83\%) が「飲み忘れたことがある」と回答していた（図 1 )。 飲み忘れの有無と漢方薬の飲みやすさに対する認識 の違いについて $\chi^{2}$ 検定を行った結果，有意な差が 認められた $(\mathrm{p}<0.05) 。$

回答者 424 人の漢方薬服用回数としては，1 日 3 回服用している患者が多く，256人（60\%）であっ た。一方，漢方薬の 1 日の希望服用回数としては, 回答者397人のうち,「2 回」と回答した患者が 243 人 $(61 \%)$ で最も多く,「3 回」が102人 $(26 \%), 「 1$ 回」が40人 (10\%) であった。

漢方薬の希望剂形としては，回答者406人のうち 「顆粒剤」と回答した患者が199人 (49\%)，「錠剂」 が190人 (47\%),「カプセル剂」が87人 (21\%) で あった。

\section{4 . 漢方薬による副作用}

回答者 435 人のうち, 漢方薬の服用により副作用 が生じたことがあると回答した患者は76人（18\%） であった。副作用の種類としては，「胃部不快感」 が最も多く，24人 (32\%) の患者に認められ，その ほか「下痢」,「腹痛」,「悪心・嘔吐」など消化器系 の副作用が多かった（表 5 ）。
表 5 漢方薬による副作用の種類 (複数回答可, 回答者 76 人)

\begin{tabular}{lc}
\hline 副作用 & 人数 $($ 人) \\
\hline 胃部不快感 & 24 \\
下痢 & 12 \\
浮腫 & 10 \\
アレルギー様症状 & 7 \\
腹痛 & 6 \\
悪心・嘔吐 & 3 \\
発汗 & 2 \\
その他 & 23 \\
\hline
\end{tabular}

\section{考察}

漢方クリニックを受診している患者の約 7 割が漢 方薬は長く飲まないと効かないと思っており，どの くらい服用して効かなかったら漢方薬の服用をやめ るか，という質問については，1 年以下の期間を挙 げた患者が約 8 割を占めていた（表 2 ）。このこと より，患者の考える「長く飲まないと効かない」と いう期間は掞よそ 1 年を目安としていることが推察 された。これに対して，漢方クリニックを受診して いる患者の約半数が漢方薬を 1 年以上服用しており

(表 2), 患者の考えと実際の治療期間には乘離が あることがわかった。しかし，この靟離に対して患 者がどのように考えているかを訊ねた結果では，患 者は 1 年以上漢方薬を服用することにほとんど抵抗 ないことがわかった。この理由としては，これらの 患者に拈いては漢方薬を服用するきっかけが，今ま での西洋医学では治らなかったこと, 対象患者に慢 性疾患が多いこと, 患者自身が漢方薬は副作用が少 ないと考えていること，漢方薬を服用した結果，一 定の効果が得られていることなどが考えられる。

漢方薬は天然の生薬からできていることから，一 般に西洋薬に比べて作用が穏やかで，副作用が少な いと考えられている。事実，漢方クリニックを受診 した理由として，「漢方薬は副作用が少ないため」 と回答した患者が多くいた（表 3 -a)。しかし， 本研究の調査では実際に副作用が起きたと回答した 患者が約 2 割もいた。本調査における副作用発現頻 度は，患者自身の判断によるものであるため，医師 の判断と合致しているかは不明であるが，胃部不快 感や下痢など比較的軽度な消化器系の症状が多く認 められた (表 5 )。漢方薬による副作用としてカン ゾウに含まれるグリチルリチンによる偽アルドステ ロン症 ${ }^{3)}$ や，小柴胡湯による薬剤性間質性肺炎(4)5 はじめ，重大な副作用の報告例がある。漢方薬は副 
作用が少ないと考えている患者が多いが，漢方薬は 医師や薬剤師の適切な服薬指導のもと, 適正に使用 される必要があろう。

漢方クリニックを受診している患者が服用してい る漢方薬はほとんどが顆粒剤であり，顆粒剤の漢方 薬を服用している患者のうち約 3 割は, 顆粒剤の漢 方薬を「味がまずい」，「粉っぽくてむせてしまう」， $\lceil 1$ 回の飲む量が多い」などの理由で「飲みにく い」あるいは「非常に飲みにくい」と回答していた

(表 4 )。これらの結果は先行研究と同様の結果で

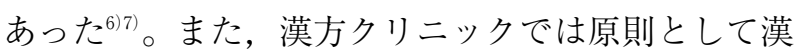
方薬服用に関して患者に服薬指導を行っているが， 本アンケート調査において，漢方薬を「飲み忘れた ことがある」と回答した患者は $73 \%$ を占め，そのう ち 1 週間に 2 回以上飲み忘れた患者が $60 \%$ いた。 佐々木らが行った漢方薬に関するアンケート調査 ${ }^{8)}$ においても，50\%の患者にノンコンプライアンスが 認められており，漢方薬は西洋薬に比べてコンプラ イアンスが悪いことが報告されている9)。さらに， 顆粒剤の漢方薬を「飲みにくい」あるいは「非常に 飲みにくい」と回答した患者では，「非常に飲みや すい」あるいは「飲みやすい」と回答した患者に比 べ，漢方薬を飲み忘れたことがあると回答した患者 の割合が高かった（図 1 )。現在製造・販売されて いる漢方薬のほとんどが顆粒剤あるいは細粒剂であ り，天然の生薬から抽出したエキス製剂であること から，多くの患者が味がまずいと感じている。また， 顆粒剤あるいは細粒剂の漢方薬の 1 回服用量は 2.5 $\sim 3 \mathrm{~g}$ と多いなどの欠点がある。このように，これ らの漢方薬の製剂的な特性が患者のコンプライアン スに影響を与えているものと考えられる。漢方薬の 剂形などは西洋薬とは違うため, 漢方薬の服用状況 やコンプライアンスなどは西洋薬とは異なるが，薬 剤師の服薬指導によって漢方薬服用中の患者のコン プライアンス向上が認められている9 。このことか ら, 薬剤師が漢方薬独特の飲みにくさを考慮に入れ た服薬指導を患者に対して行うことが，患者の更な るコンプライアンスの向上につながっていくと考え られる。

漢方薬の服用回数について, 患者は漢方薬を 1 日 3 回服用している患者が多いが，昼に飲み忘れる場 合が多く，1日の服用回数として 2 回を希望してい る患者が多くいることがわかった。西洋薬において，
患者のコンプライアンス改善を目的として 1 日 1 回 あるいは 2 回服用とするための製剂化が進んでいる。 実際に，1 日 3 回服用と比べ，1 日 2 回以下の服用 にすることにより，コンプライアンスが改善するこ とが報告されている ${ }^{1011}$ 。薬剤師に対するアンケー 卜調查に损いても，漢方薬の服用回数として 1 日 3 回に比べ，1日 2 回の方が患者にとって利益がある と回答している ${ }^{12)}$ 。さらに, 複数の漢方薬について, 服用回数を減ずることによる臨床効果および安全性 への影響はほとんどなく，コンプライアンスが向上 することが報告されている ${ }^{13) 16)}$ 。顆粒郕の漢方薬 については，吸湿性などの問題はあるが，分包し直 すことにより，1 日服用量を変更せずに 1 日 2 回の 服用が可能となる。また，漢方薬の剂形として顆粒 剂と並んで錠剂を希望している患者が多くいること がわかった。今後，1 日 2 回の服用方法を普及させ， 剤形を錠剤にするなどの製剤的な工夫をすることに より，漢方薬服用のコンプライアンスの向上が期待 できることが示唆された。

本研究の結果より, 漢方専門外来受診患者の漢方 薬に対する認識の一端が明らかとなった。今後，医 師㧍よび薬剤師は，漢方薬に対する患者のこのよう な認識を把握し，患者に適した治療を行っていく必 要があると考えられる。

謝辞 本アンケート調査を遂行するにあたり，デー 夕の収集に御協力いただきました志村彩香氏，竹澤崇 氏，武藤麻美氏，戸田雄大氏に厚く感謝いたします。

\section{引用文献}

1) 日経メディカル編集部：漢方薬使用実態調査, NIKKEI MEDICAL，10 (別冊付録)，33-38，2003

2 ) 五十嵐信智, 志村彩香, 竹澤崇, 武藤麻美, 戸田 雄大，伊藤清美，木村孝良，秋葉哲生，入江祥史， 渡辺賀子, 福澤素子, 石井弘一, 渡辺賢治, 杉山 清: 漢方薬の服用に関する実態調査 I 〜 漢方薬と 西洋薬の併用～，医療薬学，33，353-358，2007

3 ）菊地弘敏, 鎌上孝子, 木佐裕之, 出来尚史: 药薬 甘草湯により偽アルドステロン症・うっ血性心不 全を来たした 1 例, 化学療法研究所紀要, 34, 106111, 2004

4) 築山邦規, 田坂佳千, 中島正光, 日野二郎, 中浜 力, 沖本二郎, 矢木晋, 副島林造: 小柴胡湯によ 
る薬剂誘起性肺炎の 1 例, 日本胸部疾患学会雑誌, 27, 1556-1561， 1989

5 ) 佐藤篤彦, 佐藤潤：小柴胡湯による薬剤性肺炎, 漢方と最新治療，8，11-17，1999

6 ）加納公子, 松本有右, 下平秀夫, 内田寛: 漢方製 剂における剂形の検討 第 4 報一柴苓湯を服用し ている患者へのアンケート調査についてー, 薬局, 44, 673-678, 1993

7 ）浜田幸宏, 赤瀬朋秀, 田代眞一, 佐川賢一, 島田 慈彦：大建中湯エキス製剤の使用実態と剤形に関 する研究, 日本東洋医学雑誌, 54, 645-650, 2003

8 ）佐々木吉幸, 河辺玲子：当院における服薬指導の 実際（IV）－漢方薬に対する服薬状況アンケート 調査より一，薬事新報，1547，746-750，1989

9 ) 吉岡史郎, 吉岡孝: 漢方薬の服用に関する薬剤師 の関与, 臨床と研究, 81, 1021-1022, 2005

10）北島麻利子, 堀岡正義: 患者の服薬指導, 薬局, 32, 813-820, 1981

11) R.N. Greenberg : Overview of patient compliance with medication dosing: A literature review, Clin. Ther.,
6592-599, 1984

12）清原義史，前田温，大川恭子，金啓二，大西憲明, 平井みどり, 田代眞一, 松山賢治：漢方エキス製 剤に関するアンケート調査, 薬事新報, 2248, 9295, 2003

13）大原紀彦, 根本義章, 進浩和 : 医療用漢方エキス 製剂の 1 日 2 回投与による有用性の検討（第 1 報）一麻黄配合製剤の検討一, Prog. Med., 22, 151-155, 2002

14）大原紀彦，根本義章，進浩和：医療用漢方エキス 製剂の 1 日 2 回投与による有用性の検討（第 2 報）一大黄配合製剂の検討一, Prog. Med., 22, 156-158, 2002

15）大原紀彦, 根本義章, 進浩和 : 医療用漢方エキス 製剤の 1 日 2 回投与による服薬コンプライアンス に及ぼす影響一補中益気湯長期投与の検討一, Prog. Med., 22, 159-162, 2002

16）嘉数朝政，上村正和：柴苓湯エキス細粒の 1 日 2 回による有用性の検討, Prog. Med., 22, 10911094, 2002 